\title{
Growth dynamics of tree-line and lake-shore Scots pine (Pinus sylvestris L.) in the central Scandinavian Mountains during the Medieval Climate Anomaly and the early Little Ice Age
}

\author{
Hans W. Linderholm ${ }^{1}$, Peng Zhang ${ }^{1}$, Björn E. Gunnarson ${ }^{2}$, Jesper Björklund ${ }^{1}$, Emad Farahat ${ }^{1,3}$, \\ Mauricio Fuentes ${ }^{1}$, Eva Rocha ${ }^{1}$, Riikka Salo ${ }^{1}$, Kristina Seftigen ${ }^{1}$, Petter Stridbeck ${ }^{1}$ and Yu Liu ${ }^{1,4}$ \\ GULD, Regional Climate Group, Department of Earth Sciences, University of Gothenburg, Gothenburg, Sweden \\ ${ }^{2}$ Department of Physical Geography and Quaternary Geology, Stockholm University, Stockholm, Sweden \\ ${ }^{3}$ Botany and Microbiology Department, Faculty of Science, Helwan University, Cairo, Egypt \\ ${ }^{4}$ State Key Laboratory of Loess and Quaternary Geology, Institute of Earth Environment, Chinese Academy of Sciences, Xi'an, China
}

\section{Edited by:}

Valentí Rull, Botanic Institute of

Barcelona (CSIC), Spain

Reviewed by:

Jesús Julio Camarero, CSIC-Consejo

Superior de Investigaciones

Científicas, Spain

John Birks, University of Bergen,

Norway

\section{${ }^{*}$ Correspondence:}

Hans W. Linderholm, Department of

Earth Sciences, University of

Gothenburg, Box 460, 40530

Gothenburg, Sweden

e-mail: hans/@gvc.gu.se
Trees growing at their altitudinal or latitudinal distribution in Fennoscandia have been widely used to reconstruct warm season temperatures, and the region hosts some of the world's longest tree-ring chronologies. These multi-millennial long chronologies have mainly been built from tree remains found in lakes (subfossil wood from lake-shore trees). We used a unique dataset of Scots pine tree-ring data collected from wood remains found on a mountain slope in the central Scandinavian Mountains, yielding a chronology spanning over much of the last 1200 years. This data was compared with a local subfossil wood chronology with the aim to (1) describe growth variability in two environments during the Medieval Climate Anomaly (MCA) and the early Little Ice Age (LIA), and (2) investigate differences in growth characteristics during these contrasting periods. It was shown that the local tree-line during both the MCA and early LIA was almost $150 \mathrm{~m}$ higher that at present. Based on living pines from the two environments, tree-line pine growth was strongly associated with mid-summer temperatures, while the lake-shore trees showed an additional response to summer precipitation. During the MCA, regarded to be a period of favorable climate in the region, the tree-ring data from both environments showed strong coherency and moderate growth variability. In the early LIA, the two chronologies were less coherent, with the tree-line chronology showing more variability, suggesting different growth responses in the two environments during this period of less favorable growing conditions. Our results indicate that tree-ring width chronologies mainly based on lake-shore trees may need to be re-evaluated.

Keywords: Scots pine growth dynamics, central Scandinavian Mountains, Medieval Climate Anomaly, Little Ice Age, tree-line variability

\section{INTRODUCTION}

With a growing number of climate proxies extending over several centuries, the understanding of past climate variability during the last two millennia has significantly increased in many parts of the world over the last few decades. This has allowed scientists not only to gain a more coherent view of global or hemispheric climate change (Masson-Delmotte et al., 2013), but also to understand how climate has varied on regional scale. A good example of the latter is the recent efforts of the PAGES $2 \mathrm{~K}$ consortium, who utilized a wide range of climate proxies with different time resolution to reconstruct temperature variability over the last two millennia for all the continental regions of the world (Kaufman et al., 2013; PAGES 2k Consortium, 2013), which has significantly increased our understanding of spatiotemporal temperature variability across the world.

Tree-ring data are the most utilized proxy for inferring late Holocene high-resolution climate variability, mainly at high-latitudes. This is due to the possibility of gaining annually resolved data that can be calibrated against observational records. Several of the world's longest tree-ring chronologies, widely used in regional to global temperature reconstructions, come from Fennoscandia (Linderholm et al., 2010). In this region there are good possibilities to find long-lived trees (up to 700 years old) without too much human impact on their growth environments, but also trees that have been preserved in peat bogs and lakes, so called subfossil wood, for centuries to millennia (Gunnarson, 2001). Occasionally, also snags (i.e., deadwood found on standing or lying on the ground) may be found, but this is quite rare since it is a source for fire wood and has thus been depleted over the centuries, even in the more remote parts of the region.

The mix of vast natural forests with a high proportion of tree-line environments and low population density along the Scandinavian Mountains makes this an excellent area for dendroclimatological research. Since the early 2000s, several Scots 
pine tree-ring studies have emerged from this area, including multi-century to multi-millennial summer temperature reconstructions based on tree-ring width (TRW) data from the Central Scandinavian Mountains chronology (CSM), which is mainly derived from subfossil wood (Gunnarson and Linderholm, 2002; Linderholm and Gunnarson, 2005). More recently, maximum latewood density (MXD, Gunnarson et al., 2011), blue intensity (BI, Björklund et al., 2013), and carbon and oxygen isotopes (Seftigen et al., 2011), have been explored to further improve our understanding of past warm season climate variability in Central Scandinavia.

Loss in coherency between climate and tree-ring data has been a hot topic since it was first observed in high latitude North America. This "divergence" has later been defined as the inability of the studied tree-ring data to track climate target data either in the annual variability or as a mis-match of trends (D'Arrigo et al., 2008). Divergence between tree-ring data and climate has in general been discussed in a twentieth century context, but possibly it has also occurred prior to the recent era of anthropogenic influence on climate. At some northern hemisphere sites, one explanation of the divergence phenomenon is that it is a consequence of sampling strategy rather than a loss of climate sensitivity of the trees (Grudd, 2008). However, other potential "divergences" between tree-growth and climate could occur back in time, for example associated with changes in the growth environments of the trees. When sampling trees for climate reconstruction purposes, trees growing at their limit of distribution are usually chosen, since stressed trees are more sensitive to external forcing than complacent ones (Travis et al., 1990). Thus, in Fennoscandia, to reconstruct temperature, one would venture to the altitudinal or latitudinal tree limit, where temperatures during the cool and short summers usually are the main growth limiting factor for trees, to gain the best information (Linderholm et al., 2010). Accordingly, the CSM is in its most recent parts, the period which is calibrated against meteorological observations, built up from pines growing at the tree-line. Due to the bad conditions for preservation of dead wood in this environment, the older parts (> ca $1000 \mathrm{CE}$ ) of the CSM is exclusively made up by subfossil wood from mountain lakes. While some of the oldest pines have been excavated from lakes well above the present tree-line, some lakes are situated on lower elevations (Gunnarson, 2008). Moreover, the trees which will end up in the lakes have been growing on the shores of the lakes, and these lake-shore trees will be sensitive to local hydrological changes, such as varying lake water levels (Gunnarson et al., 2003). Two recent studies have shown differences in the climatic response of pines growing in lake-shore and dry environments (Düthorn et al., 2013; Helama et al., 2013). Thus, a chronology based predominantly on lake-shore trees (subfossil lake wood) back in time, may, due to local near-shore environmental growth influences or fluctuations in the thermal gradient, diverge from the general climate of the region.

The aim of this study is to investigate if any divergence in growth between lake-shore and tree-line pines can be established prior to the instrumental era. We utilize new Scots pine TRW data from drywood collected between 700 and $800 \mathrm{~m}$ a.s.l. (50$100 \mathrm{~m}$ above the present tree-line), assumed to represent the local tree-line during two periods; mid-tenth to mid-twelfth and fourteen to fifteenth centuries CE. This data are compared with subfossil Scots pine wood TRW data from lakes situated at between 500 and $700 \mathrm{~m}$ a.s.l., where some of the material has previously been included in the CSM (Gunnarson, 2008). Our hypothesis is that the pines growing at the local tree-line would be those most sensitive to summer temperatures. Thus, without having the possibility to compare our TRW data to observed meteorological data, according to our hypothesis any divergence in the subfossil TRW patterns from those of the tree-line pines would indicate a change in the climate sensitivity during two periods of supposedly differing climate conditions. This will allow us to assess if treering chronologies mainly based on lake-shore trees may contain a biased summer temperature signal. Moreover, we briefly investigate differences in growth dynamics in the periods of differing climates compared to that of today.

\section{MATERIALS AND METHODS STUDY AREA}

The study area is located in the western part of central Sweden, in the province of Jämtland. The region belongs to the Northern Boreal zone, and is situated just east of the Scandinavian Mountains main divide (Figure 1). In this area, the main topography ranges from 800 to $1000 \mathrm{~m}$ a.s.l., but scattered alpine massifs to the south reach approximately $1700 \mathrm{~m}$ a.s.l. The climate east of the Scandinavian Mountains can be described as continental, but the proximity to the Norwegian Sea, lack of high mountains in the west, as well as the east-west oriented valleys allowing moist air to be advected from the ocean, provides an influence of mild and moist westerly winds to the area. Consequently, the study area is located in a border zone between oceanic and continental climates. On short timescales, summer climate of this particular region is influenced by the atmospheric circulation, mainly the North Atlantic Oscillation (NAO), and by North Atlantic sea-surface temperature (SST) on longer timescales. Average temperatures at the closest long meteorological record are $-9.7^{\circ} \mathrm{C}$ in January and $10.8^{\circ} \mathrm{C}$ in July, and the average total annual precipitation is $633 \mathrm{~mm}$ (1961-1990; Duved, data from SMHI, Figure 1).

\section{SAMPLE COLLECTION AND PREPARATION}

In this study, we used Scots pine data derived from three different sources: living trees, preserved pieces of trees lying more or less exposed on the mountain slope (which we henceforth refer to as drywood) and subfossil wood consisting of lake-shore trees that have fallen into lakes. Details of the tree-ring data from the two environments are given in Table 1. All the data from living trees and drywood were collected in a natural reserve on the northfacing slope of the mountain Håckervalen $\left(63^{\circ} 10^{\prime} \mathrm{N}, 13^{\circ} 30^{\prime} \mathrm{E}\right.$, 775 m.a.sl., Figure 1). The environment at the northern slopes of Håckervalen is characterized by a thin till soils with interspersed blocks and exposed bedrock. The granite and gneiss bedrock has a ribbed, step like, structure where patches of mountain and dwarf birch (Betula pubescens, and Betula nana) and the occasional cluster of Norway spruce (Picea abies) are found in the flat parts. Individual young (ca. 10 years old) Scots pines were found along the sampling gradient, indicating a shift in the current tree-line. 


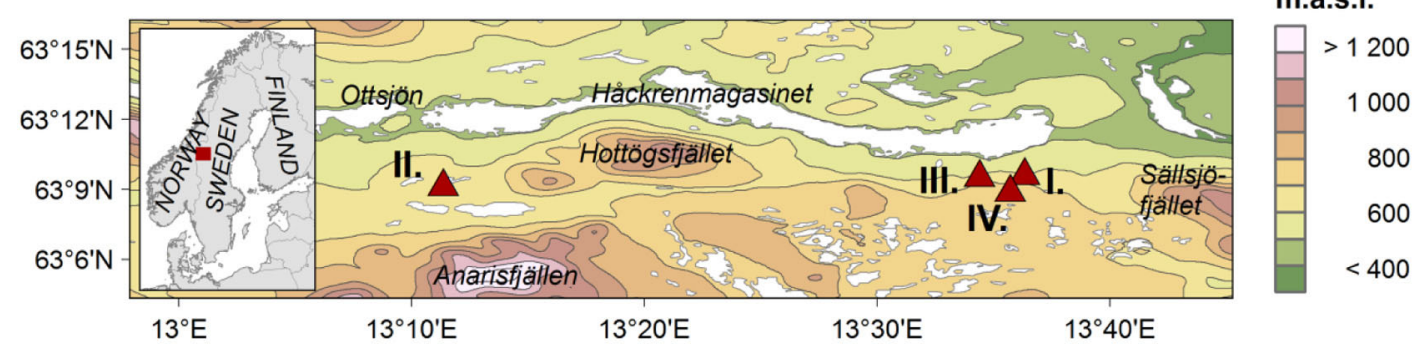

Sampling sites $\triangle$

I. Lilla-Rörtjärnen (lake) $560 \mathrm{~m}$ a.s.I. 49 subfossil wood

III. Trolltjärnen (lake) $530 \mathrm{~m}$ a.s.l., 26 subfossil wood +19 living trees

II. Ö Helgtjärnen (lake) 646 m a.s.I. 26 subfossil wood

IV. Håckervalen $700-800$ m.a.s.l, 79 drywood +

11 standing dead trees +20 living trees

FIGURE 1 | Location of the study area in west-central Fennoscandia (left), and the sampled sites (right).

Table 1 | Statistics of the tree-ring samples used in the study.

\begin{tabular}{lcccccr}
\hline Samples & NS & TA(M-A-M) & AG & TS & Rbar & MS \\
\hline TLT & 20 & $155-199-235$ & 0.99 & $1777-2012$ & 0.639 & 0.201 \\
LSLT & 19 & $68-120-287$ & 1.01 & $1726-2012$ & 0.608 & 0.190 \\
DW & 79 & $35-128-260$ & 0.78 & $709-1862$ & 0.578 & 0.204 \\
SDT & 11 & $53-129-183$ & 0.83 & $1434-1983$ & 0.490 & 0.818 \\
SW & 101 & $55-161-317$ & 0.61 & $908-1994$ & 0.585 & 0.827 \\
\end{tabular}

TLT, tree-line living trees; LSLT, lake-shore living trees; DW, drywood; SDT, standing dead trees; SW, subfossil wood; NS, number of samples; TA(M-A-M), tree age (min-average-max); $A G$, average growth (mm); TS, time span; Rbar, mean inter-series correlation; MS, mean sensitivity; AC1, first-order autocorrelation.

The vegetation mainly consists of ericaceous shrubs indicating a rather dry environment. In this specific area, drywood can be found within the present-day forest and up to just below the $800 \mathrm{~m}$ level, and here we mainly focused on samples from above the present day tree-line. From the drywood, discs (ca. $5 \mathrm{~cm}$ thick) were taken using a chainsaw (Figure 2). In many cases, the samples were heavily eroded, so only parts of the stem were possible to obtain. Moreover, only those displaying more than 50 rings (from ocular inspection) were taken. The sampling strategy was to obtain as many rings per sample as possible, so stem sections were cut to expose the cross sections that eventually provided the highest amount of rings. Discs were taken as close to the root as possible, avoiding both reaction wood and the part closest to the root which is usually disturbed. In total, 79 drywood samples were collected. To attempt to connect the time series from the drywood samples with those off the living trees, 11 standing dead trees were also sampled close to the present tree-line. Samples from 20 living trees, assumed to be comparable to the drywood, were collected from the present tree-line at approximately $650 \mathrm{~m}$ a.s.l. From both standing dead and living trees, two samples were taken from each tree (at least $90^{\circ}$ apart) at ca. $1.3 \mathrm{~m}$ above the ground.

To represent lake-shore pines from the past, we used subfossil wood from two small lakes on northern slope of Håckervalen, downslope of the drywood site: Trolltjärnen (530 $\mathrm{m}$ a.s.l.) and Lill-Rörtjärnen $560 \mathrm{~m}$ a.s.l, (Figure 1). Samples from the latter lake have previously been described (Gunnarson, 2001) and are included in the CSM. Samples from Trolltjärnen were collected in 2012-2013. In these small mountain lakes, pine and spruce trunks can be found lying at the surface, slightly covered by sediments. Once removed, older samples can be found embedded in the sediments. To sample the subfossils, a diver attached a hook to the logs under the water and they were winched onto the shore (Figure 2). Subsequently, all logs were cut with a chainsaw, extracting approximately $5 \mathrm{~cm}$ thick discs. If possible, the discs were taken at about $1-1.5 \mathrm{~m}$ above the original root level (similar to the living trees). However, logs with poorly preserved lower sections were cut higher up. From the two lakes on the slopes of Håckervalen, 26 samples from Trolltjärnen and 49 samples from Lill-Rörtjärnen were dated (see below) to the period of interest, so to boost the replication we added previously sampled subfossil data from a nearby lake south of Lake Håckren (Figure 1): Östra Helgtjärnen $646 \mathrm{~m}$ a.s.l, (26 trees). Samples were also taken from 19 living lake-shore pines growing on the shore of Trolltjärnen using the same sampling strategy as for the living tree-line trees.

The samples from the living trees were prepared according to standard dendrochronological techniques (Stokes and Smiley, 1968), and preparation of the subfossil samples according to the protocol used by Gunnarson (2001). Annual TRW were measured with a precision of $\pm 0.001 \mathrm{~mm}$ using a stereomicroscope coupled to a Lintab measurement table connected to the Time Series Analysis Program (TSAP) software (Rinntech, Heidelberg, Germany). For each pair of measurements (i.e., within tree samples), sign tests, which calculate the agreement of all positions of overlap between tree-ring series, and student's $t$-test values 


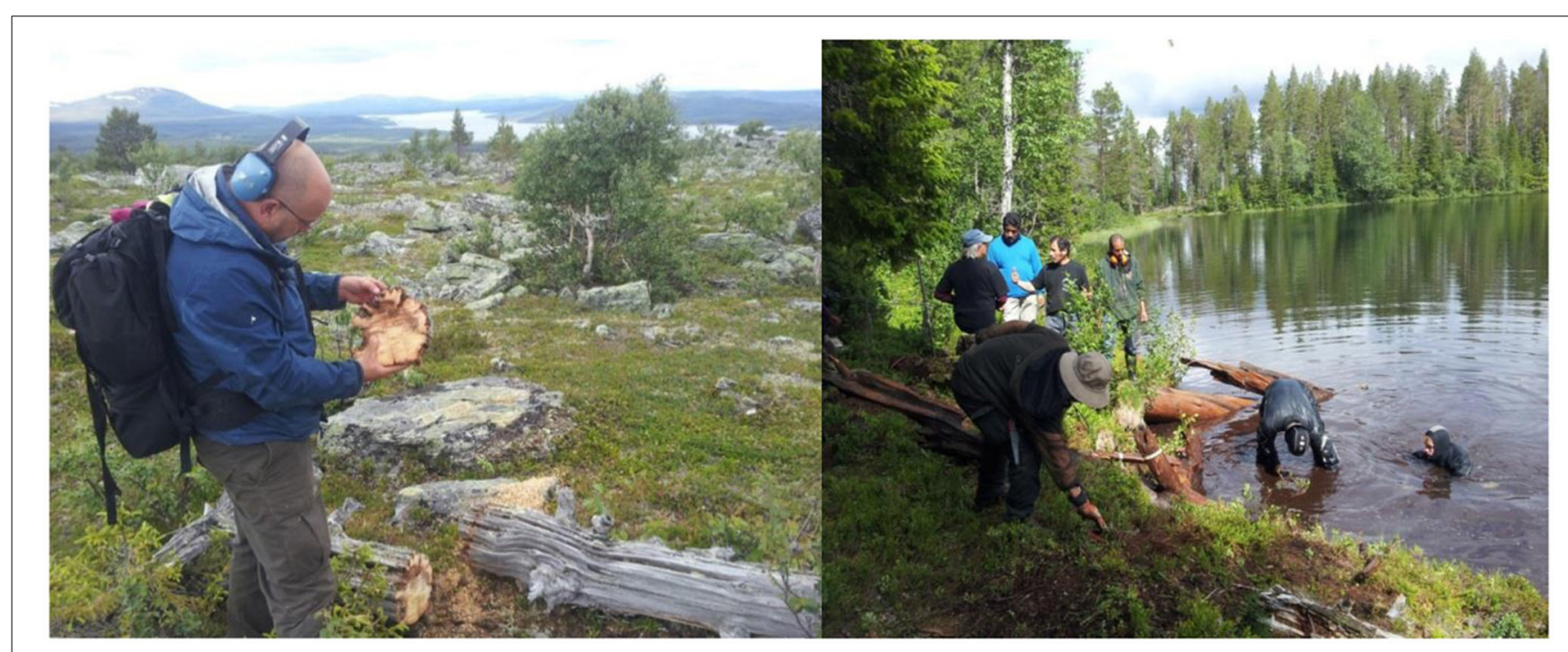

FIGURE 2 | Sampling of drywood at Håckervalen (left) and of subfossil wood at Trolltjärnen (right).

were calculated to ensure that the within radii were in agreement. If well correlated, the two radii from each tree were averaged into one tree-ring series for each tree, and subsequently all tree-ring series were cross dated against each other. After visual and statistical control, tree-ring series with good matches, high $t$ - and sign-test values were checked statistically using the software COFECHA, which analyses the quality of a set of tree-ring measurements, verifies cross-dating among tree-ring series and indicates possible dating or measurement problems (Holmes, 1999). Tree-ring series with good visual agreement and high correlation (usually trees with a correlation of $>0.5$ with the mean were used, but in some cases trees with slightly lower correlation were selected after visual confirmation of good agreement) among trees were included in the master chronology for the area. For the living trees, the assemblage of a chronology was straight forward, since the year of the lastly formed ring was known. Since the ages of the dry-wood and subfossil samples were unknown, the cross-dating procedure was more time consuming. However, since there already exists a multi-millennial tree-ring with chronology from Jämtland (Gunnarson, 2008), we utilized this to date the samples.

\section{STANDARDIZATION AND CHRONOLOGY BUILDING, AND CLIMATE ANALYSIS}

TRW are observed to vary with cambial age, i.e., with increasing age and circumference they will usually exhibit a persistent decrease. This is termed the biological age trend. To enhance the information in the tree-ring data associated with climate, this age trend needs to be removed. This is commonly done by division of ordinary least square fitted data-adaptive smoothing curves from each tree-ring series (Cook, 1985). The resulting index will then ideally reflect the climate forcing upon the trees. In this study we used a conservative standardization method, viz. fitting a negative exponential curve, or a regression line, to the ringwidth series and then dividing each observed ring-width value by the corresponding curve. The detrended individual series were then averaged into non-dimensional chronologies for the two growth environments. Standardization was performed with the ARSTAN software (Cook et al., 2007), and we used the standard chronologies (STD) in our analysis. To estimate the reliability of the tree-ring data, we used the expressed population signal (EPS) criterion (Wigley et al., 1984). The EPS represents the percentage of the variance in a hypothetical population accounted for by the sample, here calculated for 50-year moving windows with a 25 -year lag. A value above 0.85 is generally considered adequate. Even though focus was on the pre-instrumental era, we tested the association between two climate parameters and the TRW chronologies from the living tree-line and lakeshore pines. Temperature and precipitation were taken from the nearest grid point $\left(\mathrm{N} 63.0-63.5^{\circ}, \mathrm{E} 13.5-14.0^{\circ}\right)$ from the CRU TS3.10 dataset (Harris et al., 2014). Pearson correlation coefficients were calculated for each month from January to September 1901-2008 using DendroClim 2002 software (Biondi and Waikul, 2004).

\section{RESULTS \\ SPATIOTEMPORAL DISTRIBUTION AND GROWTH PATTERNS OF THE SAMPLES}

In Figure 3, the temporal distribution of all samples is given. The oldest trees grew during the ninth and tenth century CE for the drywood and subfossil wood samples, respectively, while the youngest ones had lived during the twentieth century. However, the majority of the samples from both environments were clustered in two main periods. Both periods roughly cover two centuries each, where the first period, between ca 950 and 1150, coincides with the Medieval Climate Anomaly (MCA, or Medieval warm epoch, Lamb, 1965). The other pronounced period, between ca 1300 and $1500 \mathrm{CE}$ corresponds to the early part of the Little Ice Age (LIA, ibid.) After ca 1500, there is a sharp decline in the drywood sample number, until the inclusion of samples from living trees in the 1800s. The pattern differs when the subfossil trees are concerned, where there is 

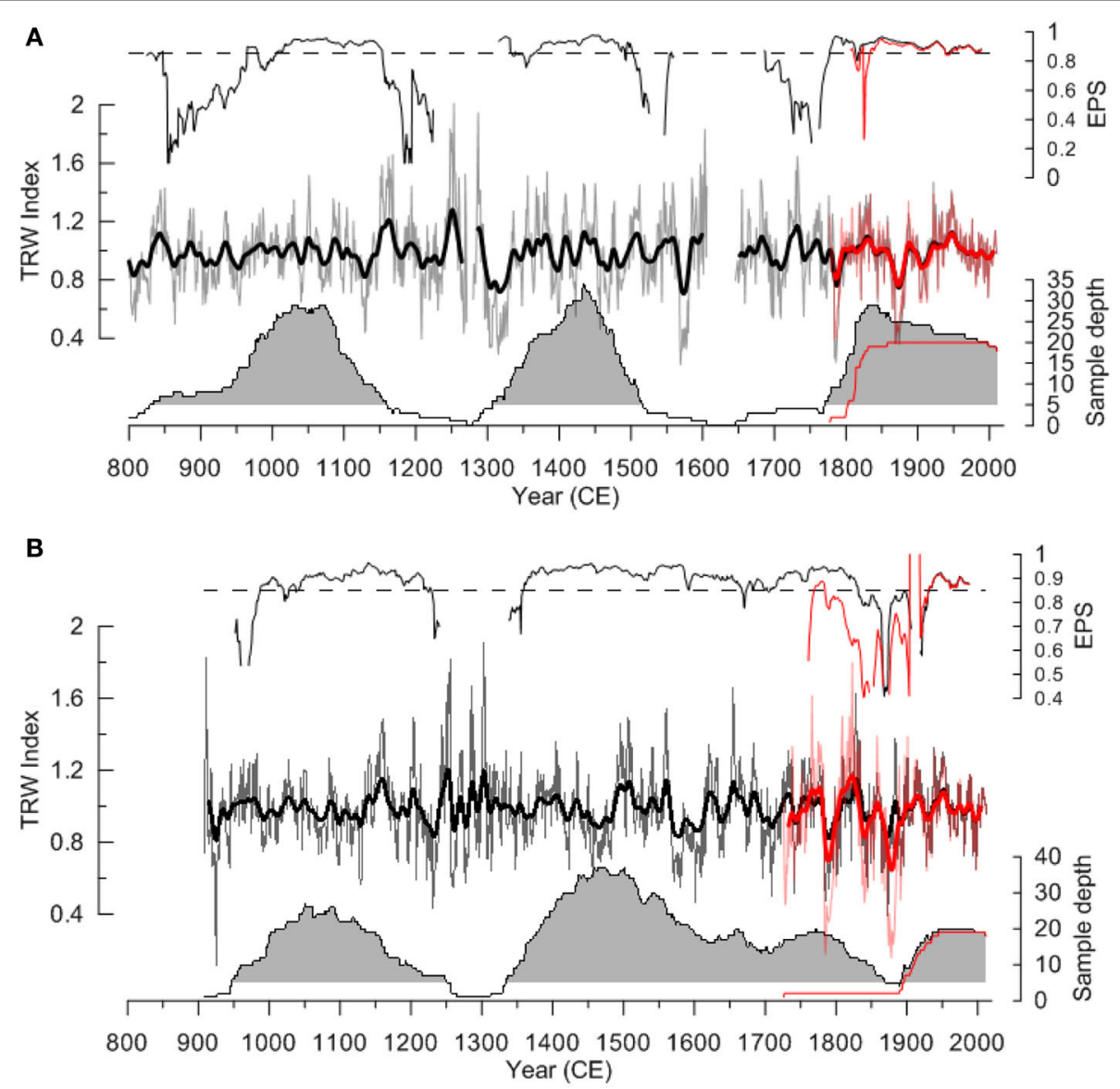

FIGURE 3 | Tree-ring width indices, sample replication, and EPS statistics for the (A) tree-line (drywood) chronology, and (B) the subfossil

(lake-shore) chronology. Thick line shows smoothed chronologies with a 15-year low-pass Gaussian-weighted filter. Red curves show the chronology (bold) and the sample depth (thin) with living-tree samples involved. Gray shading indicates when more than five samples have been used. Note that the subfossil chronology is a composite chronology from several lakes in the area (see text and Figure 1), while the drywood chronology is from one site only. a gradual decrease in sample number until it trails off in the mid-1850s.

The two standardized chronologies, and their corresponding EPS values, are also shown in Figure 3. The drywood chronology spans 709-2011, where the living trees cover the last period 1675-2012, and two gaps were found in 1272-1279 and 16071646. The subfossil chronology spans 908-2012 with no gaps. The majority of the youngest subfossil trees died in the early 1800s, but the last subfossil tree died in 1994. The EPS values (reliability) of the drywood chronology vary with numbers of samples, reaching $>0.85$ only in the best replicated periods. Due to a slightly higher, and more even, replication through time the EPS value is more consistent for the subfossil chronology. To reduce the influence of low replication on the chronologies we now focus on the two reasonably well replicated periods 950-1160 and $1320-1500$.

Turning to the GPS derived elevational distribution of the samples, Figure 4 shows 50 of the 79 drywood samples from Håckervalen (unfortunately the remaining 29 samples could not be GPS positioned, but they were all found within the upper and lower elevation boundaries). The growing period of each individual tree was calculated by averaging the birth year and death year of each sample. No changes in the local tree-line from the MCA to the early LIA are evident. In fact, more samples from the latter period were found in the upper part of the elevation span, but this may be due to the exposure time: the risk of decay and weathering of the drywood increases with time.

Comparing the growth indices of the two chronologies for the two periods of interest, changes in their association as well as their characteristics can been noted. In the early (MCA) period, the chronologies are significantly correlated during most of the time, and they show consistent variability on both interannual and decadal timescales (Figure 5). A slightly higher variability is seen in the drywood chronology throughout this period, which could indicate a slightly higher sensitivity of the tree-line trees during the MCA. The high variability in the subfossil chronology during the first 50 years seen in the 1st differenced data is likely due to low replication. Over all the tree-ring data indicate quite stable conditions between 950 and 1050, after which the growing conditions become more variable ending with an increasing growth trend in the last decades. In the early LIA 


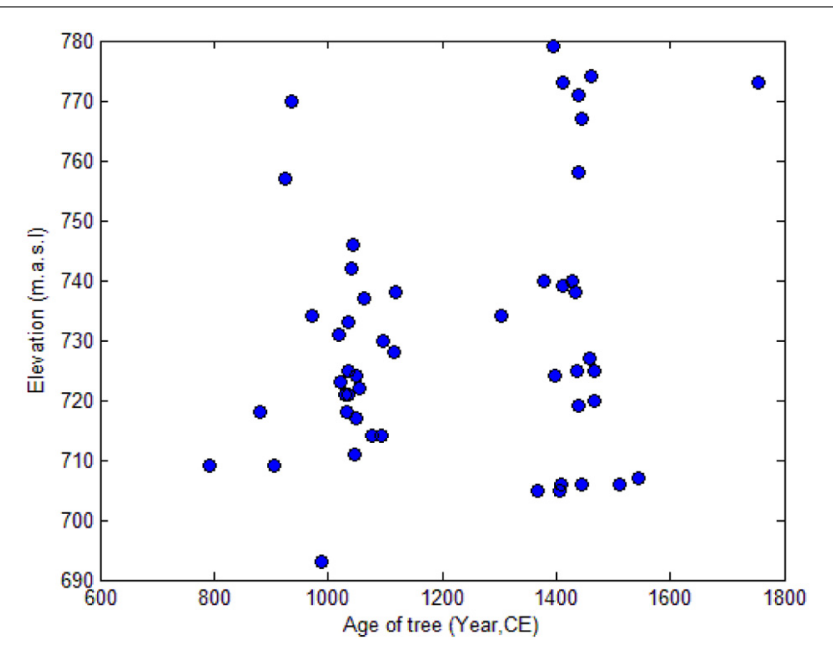

FIGURE 4 | Scatter plot of the elevation of each individual tree and its growing period of the tree in Håckervalen. Note that not all 79 drywood trees are plotted in this figure. period, there is less agreement between the chronologies as indicated by the visual discrepancy between the series and the running correlation (Figure 5). Compared to the MCA, the growth conditions appear to have been more variable at the tree-line, characterized by more variability on decadal timescales. Also the year-to-year variability (1st difference) is more pronounced during this period, especially during the first 100 years during this period, likely indicating a more variable summer climate. The difference from the earlier period in terms of growth variability in the subfossil data is not as conspicuous as in the tree-line data, although a change to more variable growth conditions may be discerned.

Additional information about the growth conditions can be gleaned from the absolute pine growth ( $\mathrm{mm} /$ year) averaged over the two periods in question. Since both drywood and subfossil wood usually are quite weathered, it is highly unusual to find samples that contain the outermost parts of the wood (the sapwood) which is more easily eroded that the heartwood. Moreover, in a large quantity of the drywood samples, also the innermost part of the wood was missing. To estimate the average growth, we removed the juvenile growth phase of the all the samples in which it was present in order to get a fairly unbiased average for each year. Usually, tree growth will decline with age (as a function of the tree circumference getting larger), and this could have caused another bias. However, as noted above, since most of the outermost rings were eroded, this was not considered to have any significant influences on the result. Annual growth averages were made over three 150-year periods; in the MCA, the early LIA and in the most recent one (1850-2000). From Figure 6 we see that the average growth at the tree-line site has been quite stable at around $0.75 \mathrm{~mm} /$ year over the three periods, where the highest averages were surprisingly found during the early LIA. A different pattern is evident in the subfossil trees, where MCA A growth of ca. $0.8 \mathrm{~mm}$ /year was slightly higher than at the treeline. The early LIA shows a distinct reduction in average growth to about $0.7 \mathrm{~mm} /$ year, which is lower that at the tree-line. The most conspicuous change is the increase in last 150 years, where the average growth of ca. $0.9 \mathrm{~mm} /$ year is well above that of the MCA as well as the concurrent tree-line pine growth. Thus, in terms of annual growth, the tree-line pines are more stable than the lake-shore trees, where the latter seem to have responded to the recent warming more favorably.

\section{TREE-RINGS AND CLIMATE}

The results from the correlation analyses (Figure 7) show much of the expected patterns of associations with temperature and precipitation for the tree-line pines. Significant correlations and positive are only found in July (1st diff. and STD) and August (STD). The strong association with mid-summer temperatures corresponds with previous results from the area (e.g., Gunnarson and Linderholm, 2002). The correlation pattern for the lake-shore trees is slightly different. In addition to significant positive correlations with temperature in June (1st diff.), July (1st diff. and STD) and August (1st diff.), TRW is significantly and negatively correlated to precipitation in July and August (both 1st diff.).

\section{DISCUSSION}

The dendrochronological material presented in this study is quite unique, especially regarding the temporal distribution of the drywood material. It has previously shown that lakes in Fennoscandia can, under the right conditions, contain subfossil wood reaching back in time for several millennia reaching over more or less the whole ice-free period after the last glacial (Grudd et al., 2002; Gunnarson, 2008; Helama et al., 2008). When it comes to wood preserved on the ground, much less material is available. Even in favorable environments (cool and short summers), there is a limit to how long such material can remain before it decays. Moreover, much of the snag material has likely been removed to be used mainly to make fires, both by indigenous people, e.g., when herding reindeer, but also by tourists. Tree remains found at different elevations have been used to infer past tree-line variations (e.g., Karlén and Kuylenstierna, 1996), but such studies have mainly been based on scattered samples collected over large areas. The notable thing with the Håckervalen material is the wealth of material found as well as the temporal distribution of it. In fact, during the almost 20 years of fieldwork in the region, this is the first finding of such a coherent drywood material.

\section{TREE-LINE VARIABILITY}

One interesting result of the study was the relative stability of the inferred tree-line elevation when the MCA and the early LIA are concerned. The a priori assumption was that the MCA trees would be found at a higher elevation relative to those from the early LIA period with presumably less favorable climate, since the tree-line is strongly correlated with temperature and a good bioindicator of climate change and variability (Kullman and Öberg, 2009). However, this turned out not to be true. Trees having lived during both the MCA and early LIA were found up to the $800 \mathrm{~m}$ level (Figure 4), implying no tree-line elevation drop during the transition from the MCA to the LIA. Based on the TRW chronologies, there is no support of distinct changes 


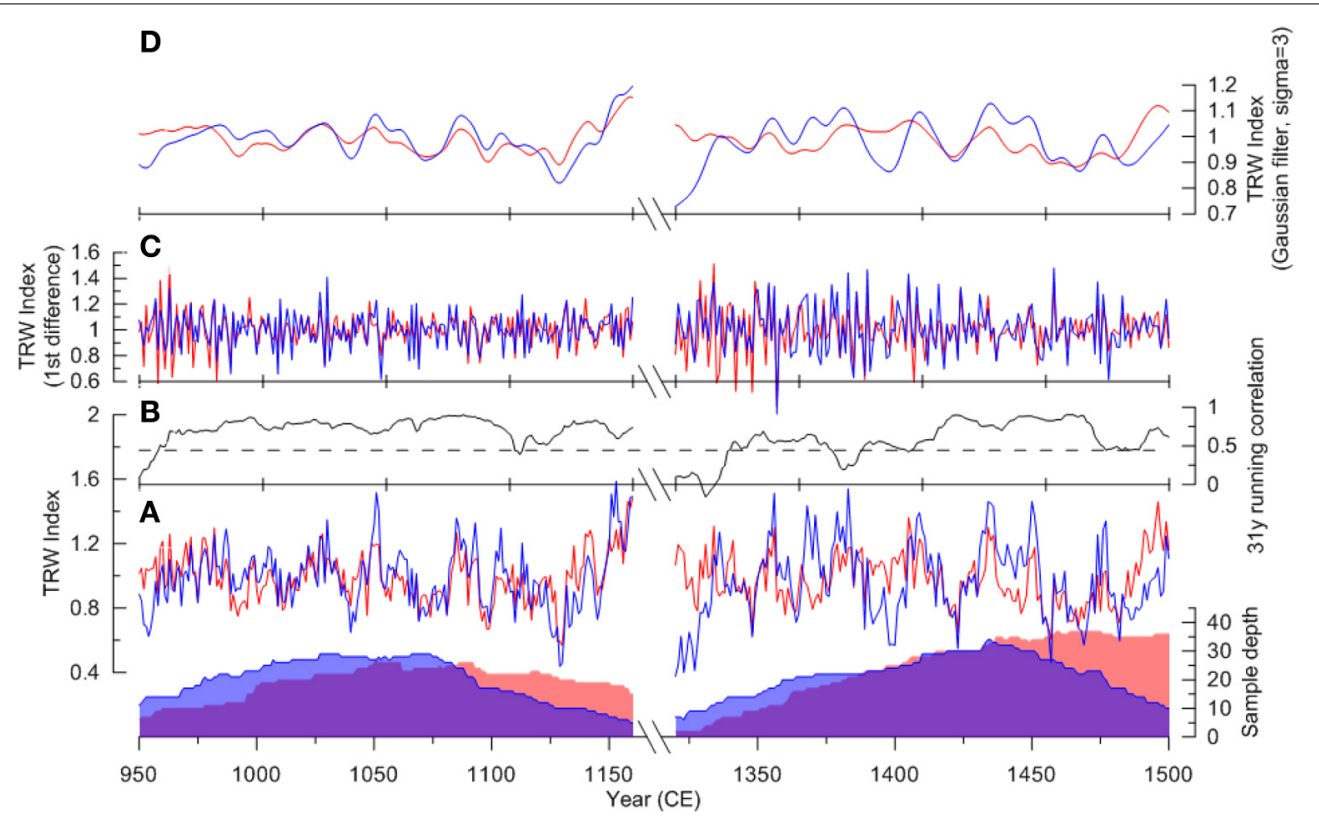

FIGURE 5 | Comparison of raw (A), interannual (C), and decadal (D) growth patterns between the drywood (blue) and the subfossil (red) composite tree-ring width (TRW) chronologies in the period of 950-1160 CE and 1320-1500 CE. Also shown is the running correlation (B, 31-year window) between the two chronologies.

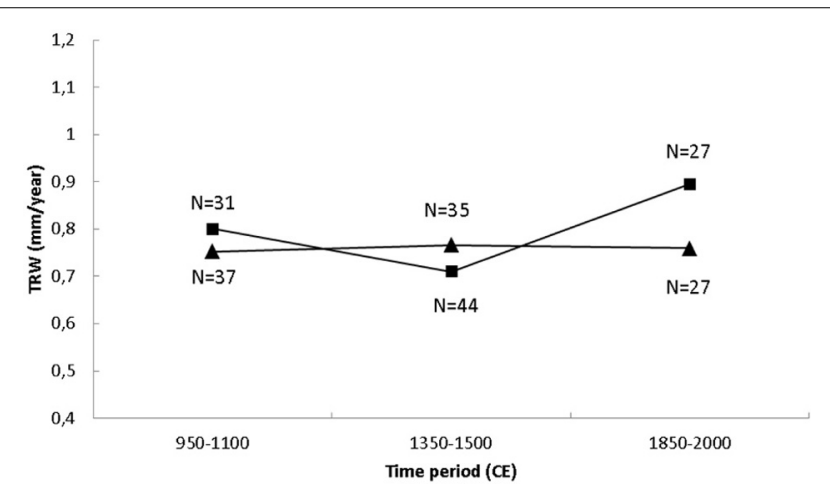

FIGURE 6 | Measured yearly Scots pine growth (in $\mathrm{mm}$ ) averaged over three 150-year windows: 950-1100 CE, 1350-1500 CE, and 1850-2000 CE for the tree-line (triangle) and lake-shore (square) samples. Here the juvenile phase of the growth was removed before the averaging. $\mathrm{N}$ is the number of the samples used in the calculations of the mean tree-ring widths.

in growing season climate from the early period to the late one. The abrupt decrease in samples in both environments during the 1200s, suggests a drop in regeneration, but either the treeline remained at around $800 \mathrm{~m}$, or there was a recovery from lower levels in the 1300s. Most likely the ensuing tree-line decline occurred during the colder stages of the LIA when widespread tree mortality and regeneration failure occurred (Kullman, 2007), but due to the gaps in the available drywood data we cannot date this decline. Reported increases in the pine tree-line in the southern Scandinavian mountains of on average ca. $80 \mathrm{~m}$ (19152007, Kullman and Öberg, 2009), suggests a significant decline in the tree-line of about $300 \mathrm{~m}$ from the LIA to the early part of the twentieth century. However, contrary to the reasoning by Kullman and Öberg (2009), the present-day pine tree-line of $650 \mathrm{~m}$ a.s.l. has not yet reached up to (or slightly above) the MCA position.

\section{TREE-RINGS AND CLIMATE-MCA}

At Håckervalen no significant differences between the growth patterns of the tree-line and the lake-shore trees were evident during the MCA. The chronologies show coherent growth variability $(r=0.70)$ and also agree well on multidecadal timescales, indicating a similar response to climate during this period. In Fennoscandia, summer climate during the MCA has been inferred to be warm (Esper et al., 2012) and dry (Helama et al., 2009a). Conversely, the TRW data from both sites, displaying low short and long-term growth variability, indicates that the MCA was a period of stable and favorable summer conditions. Our results can be interpreted so that during times of favorable climate the site selection is of less importance when the common signal in the TRW data is concerned. During this period of warm and dry conditions it is likely that the lake levels were low, causing the response to climate of the lake-shore trees to be similar to those growing in a drier environment. The general higher growth variability seen in the tree-line chronology may indicate a slightly higher sensitivity to anomalous weather conditions compared to that of the subfossil wood. This implies that subfossil wood may not be able to capture extreme events as well as their tree-line counterparts during periods of generally favorable conditions.

We interpret the low sample replication at both sites in the mid-1200s to be an indication of unfavorable regeneration in the late stages of the MCA. Sudden changes in climate, such as an 


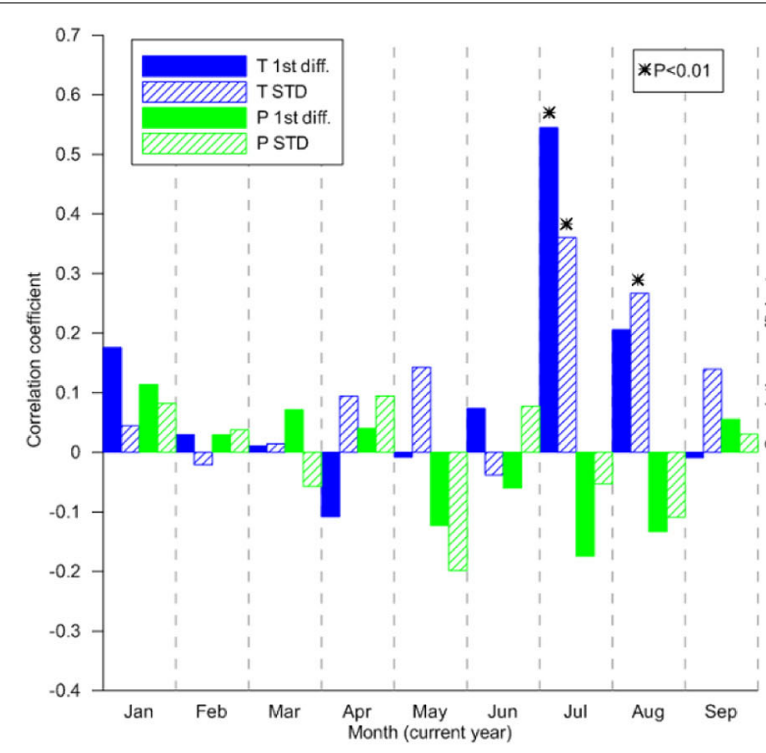

FIGURE 7 | Pearson correlation coefficients between 1st differenced (solid bar)/standardized (shaded bar) ring-width indices from (left) tree-line living tree chronology (Håckervalen 20 trees), (right) lake-shore

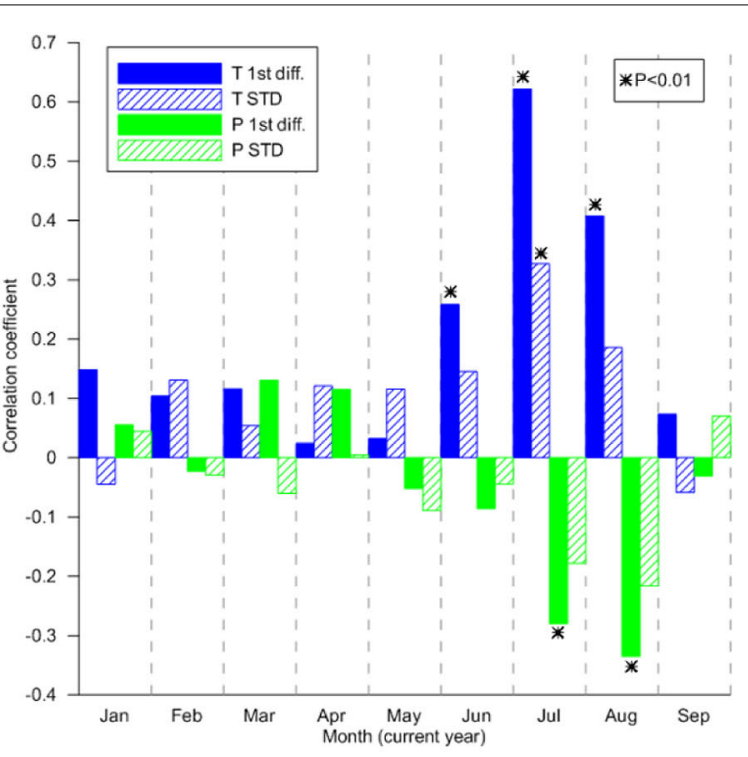

living tree chronology (Trolltjärnen, 19 trees) and temperature ( $T$, blue/dark) and precipitation (P, Green/light) from the closest grid-point in the CRU TS3.10 dataset (Harris et al., 2014) 1901-2008. increased frequency of very low temperatures, around this time have been indicated in many paleoclimate records (e.g., Luckman and Wilson, 2005; Helama et al., 2009b; Büntgen et al., 2011; Esper et al., 2012). The shift to these cooler conditions, lasting several decades, may have been set off by a colossal volcanic eruption that took place in 1257 or 1258 CE (Lavigne et al., 2013). Regardless of the cause of this abrupt change in climate across the northern hemisphere, it did have a strong impact on tree growth in the CSM.

\section{POSSIBLE IMPACTS OF FIRES ON THE TEMPORAL SAMPLE DISTRIBUTION}

It should be noted that the variability of sample availability through the whole period can also be an effect of other environmental factors, such as fire disturbances. Fires ignited by lightning are a natural phenomenon in Scandinavia, and it can affect and trigger pulses of mortality and recruitment of forest species, driving the development of stand generations from uneven-aged to relatively even aged or well defined age intervals in forest stands (Zackrisson, 1977; Niklasson and Granström, 2000). These fire events can become registered as scars in the wood, which subsequently are overgrown by the tree. We dated scars present in some of the drywood samples $(n=7)$, that probably were caused by forest fires. They dated to 892, 1384, 1422-1423, and 1454 CE. In addition, a report by the local county administration (Länsstyrelsen Jämtlands Län, 2007) suggests that forest fires affected the area in ca. 1637, 1700, 1800, and 1860-1870 CE, where some of these dates can be related to sample depth for example in Figure 3A.

\section{TREE-RINGS AND CLIMATE-EARLY LIA}

The increase in samples suggests that summer climate became favorable for regeneration again in the fifteenth century. Since the LIA was a climatically variable period, both in time and in space (see e.g., PAGES 2k Consortium, 2013), it is difficult to give an exact date of the start of this period. However, in general the LIA is often described as spanning ca. 1350-1850 CE (IPCC, 2007). In Fennoscandia, proxy data indicate a long term trend toward cooler summer temperatures from the early fifteenth century, culminating in the very cold period around 1600 CE (e.g., Helama et al., 2009b; Ljungqvist, 2010; Gagen et al., 2011; Gunnarson et al., 2011). There is limited information on precipitation changes in the early LIA, but isotopes from tree rings and lake sediments from northern Scandinavian indicates that wet summers occurred between ca. 1300 and 1450 (Young et al., 2012; Rosqvist et al., 2013), while moisture sensitive tree-ring data from Finland indicate that this was quite a dry period (Helama et al., 2009a). Moreover, glacial expansion in Norway (Dahl and Nesje, 1994), an extended period of positive NAO (Trouet et al., 2009), increasing lake levels in Finland (Nevalainen et al., 2013), as well as high return intervals of forest fires in Sweden (Drobyshev et al., 2014) all indicate an increase in precipitation during this particular period. The effect of this change in climate was most evident in the lakeshore material. While the average growth remains equal when compared to the MCA at the dry site, there was a clear reduction at the wet site. Also, there was far less coherence among the two chronologies in this period $(r=0.49)$, and both time series show more variability on interannual to mulidecadal timescales. The implication of these observations is that the early LIA had a more variable summer climate than the MCA, but seemingly it was not affecting the dry-site trees as much as the lake-shore trees. Possibly the trees growing at the tree-line on relatively well-drained soils were not as strongly affected by the change to wetter conditions (winter and/or summer) and/or cooler summers with less evapotranspiration as the lake-shore 
trees which would be influenced by the resulting increased lake levels.

\section{TREE-RINGS AND CLIMATE-PRESENT DAY}

The results from the correlation analysis indicate a slightly different response to climate of pines in the two environments. The strong association between July temperatures and pine growth at the tree-line trees was expected, and is in agreement with previous studies across Fennoscandia (see Linderholm et al., 2010). The sensitivity of the lake-shore pines to precipitation, in addition to the positive summer temperature association, is likely linked to lake-level variability. Similar results were obtained by Helama et al. (2013), comparing lake-shore and upland trees in Finland. However, in addition to positive associations with summer temperature, they found a strong negative impact of winter precipitation on lake-shore trees. Previously Gunnarson (2001) discussed the role of lake-level fluctuations on the temporal distribution of subfossil material in the lakes, with a view of the long-term impact of hydrological changes on lake-shore pine populations. However, our results also indicate an effect on the growth variability of these trees.

\section{IMPLICATIONS OF THE RESULTS}

One of the aims of this study was to investigate potential biases in the temperature signal derived from lake-shore trees and those from trees growing in drier environments, e.g., at the tree-line. Discrepancies between pines from respective environments have been noted in studies based on living trees (Düthorn et al., 2013; Helama et al., 2013). Although no attempts have been made to assess this relationship further back in time, our unique treeline data, covering parts of the last millennium, made it possible to assess the nature of this relationship back in time. Despite being able to corroborate our findings with meteorological data, assuming that pines growing at the tree-line contain the strongest temperature information when it comes to TRW data, we may still draw some conclusions based on our findings. Consequently, the observed "divergence" in the growth patterns as well as variability between the two growth environments during the early LIA could illustrate a loss of temperature sensitivity in the lake-shore trees due to wetter and milder summer conditions. Even though the lake-shore trees at the time may be sensitive to temperature fluctuations, the added effect of changing hydrological conditions may have distorted this signal, both on short (interannual) and long (decadal and longer) timescales. The low decadal variability and disability to capture extreme years, compared to the treeline pines, during the early LIA supports this. The implication of these results could be that the Fennoscandian multi-millennial TRW chronologies, which mainly consist of lake-shore subfossil material, should be re-evaluated. Without a more coherent temporal coverage of pine tree-ring data, it is difficult to further address this issue, e.g., comparing the two types of pines during the remainder of the LIA. Still, the development of MXD and BI chronologies, which contain far stronger summer temperature signals that TRW data (e.g., Grudd, 2008), for the last 1200 years in the region will provide an opportunity to further investigate potential temperature biases in the lake-shore subfossil data.

\section{CONCLUSIONS}

Analysing Scots pine TRW data from drywood collected between 700 and $800 \mathrm{~m}$ a.s.l. assumed to represent the local tree-line and subfossil lake-shore data from lakes we can draw the following conclusions:

- The local tree-line during the MCA and early LIA of ca. $790 \mathrm{~m}$ a.s.l. was about $140 \mathrm{~m}$ higher than the present one.

- During the MCA, assumed to be a period of favorable climate, pines from both environments showed coherent growth patterns on both short and long timescales.

- The early LIA, presumed to be a period of wetter and colder summers, was, however, characterized by less coherency between the sites, where the subfossil pines showed less variability (interannual-to-decadal timescales) that the tree-line pines.

- The implication of our results is that lake-shore trees may lose some of their sensitivity to temperature during wetter periods. As a consequence, temperature reconstructions based predominantly on subfossil lake-shore trees may need to be re-evaluated.

\section{ACKNOWLEDGMENTS}

First of all we would like to thank the County Administrative Board of Jämtland for the permission to sample trees in a natural reserve. We also thank Paul Krusic, Amarita Krusic, Ugeyn Dorji, Peter Seftigen, and Daniel Yrgaw for assistance in the field. This research contributes to and the Swedish strategic research areas Modeling the Regional and Global Earth system (MERGE), and Biodiversity and Ecosystem services in a Changing Climate (BECC). This is contribution \# 28 from the Sino-Swedish Center for Tree-Ring Research (SISTRR).

\section{REFERENCES}

Biondi, F., and Waikul, K. (2004). DENDROCLIM2002: a C++ program for statistical calibration of climate signals in tree-ring chronologies. Comput. Geosci. 30, 303-311. doi: 10.1016/j.cageo.2003.11.004

Björklund, J. A., Gunnarson, B. E., Krusic, P. J., Grudd, H., Josefsson, T., Östlund, L., et al. (2013). Advances towards improved low-frequency treering reconstructions, using an updated Pinus sylvestris L. MXD network from the Scandinavian Mountains. Theor. Appl. Climatol. 113, 697-710. doi: 10.1007/s00704-012-0787-7

Büntgen, U., Tegel, W., Nicolussi, K., McCormick, M., Frank, D., Trouet, V., et al. (2011). 2500 years of european climate variability and human susceptibility. Science 331, 578-582. doi: 10.1126/science. 1197175

Cook, E. R. (1985). A Time Series Analysis Approach to Tree-Ring Standardization. Ph.D. Dissertation, University of Arizona.

Cook, E. R., Krusic, P. J., Holmes, R. H., and Peters, K. (2007). Program ARSTAN Ver. ARS41d. Available online at: www.ldeo.columbia.edu/tree-ringlaboratory

Dahl, S. O., and Nesje, A. (1994). Holocene glacier fluctuations at Hardangerjøkulen, central-southern Norway: a high-resolution composite chronology from lacustrine and terrestrial deposits. Holocene 4, 269-277. doi: 10.1177/095968369400400306

D'Arrigo, R., Wilson, R., Liepert, B., and Cherubini, P. (2008). On the 'divergence problem' in northern forests: a review of the tree ring evidence and possible causes. Global Planet. Change 60, 289-305. doi: 10.1016/j.gloplacha.2007. 03.004

Drobyshev, I., Granström, A., Linderholm, H. W., Hellberg, E., Bergeron, Y., and Niklasson, M. (2014). Multi-century reconstruction of fire activity in Northern European boreal forest suggests differences in regional fire regimes 
and their sensitivity to precipitation. J. Ecol. 102, 738-748. doi: 10.1111/13652745.12235

Düthorn, E., Holzkämper, S., Timonen, M., and Esper, J. (2013). Influence of micro-site conditions on tree-ring climate signals and trends in central and northern Sweden. Trees 27, 1395-1404. doi: 10.1007/s00468-0130887-8

Esper, J., Büntgen, U., Timonen, M., and Frank, D. C. (2012). Variability and extremes of Northern Scandinavian summer temperatures over the past two millennia. Global Planet. Change 88-89, 1-9. doi: 10.1016/j.gloplacha.2012. 01.006

Gagen, M., Zorita, E., McCarroll, D., Young, G. H. F., Grudd, H., Jalkanen, R., et al. (2011). Cloud response to summer temperatures in Fennoscandia over the last thousand years. Geophys. Res. Lett. 38, L05701. doi: 10.1029/2010GL 046216

Grudd, H. (2008).Torneträsk tree-ring width and density AD 500-2004: a test of climatic sensitivity and a new 1500-year reconstruction of north Fennoscandian summers. Clim. Dyn. 31, 843-857. doi: 10.1007/s00382-007$0358-2$

Grudd, H., Briffa, K. R., Karlén, W., Bartholin, T. S., Jones, P. D., and Kromer, B. (2002). A 7400-year tree-ring chronology in northern Swedish Lapland-natural climate variability expressed on annual to millennial time scale. Holocene 12, 657-665. doi: 10.1191/0959683602h 1578rp

Gunnarson, B. (2001). Lake level changes indicated by dendrochronology from subfossil pine found in Jämtland, central Sweden. Arct. Antarct. Alp. Res. 33, 274-281. doi: 10.2307/1552234

Gunnarson, B. E. (2008). Temporal distribution pattern of subfossil pines in central Sweden: perspective on Holocene humidity fluctuations. Holocene 18, 569-577. doi: 10.1177/0959683608089211

Gunnarson, B. E., Borgmark, A., and Wastegård, S. (2003). Holocene humidity fluctuations in Sweden inferred from dendrochronology and peat stratigraphy. Boreas 32, 347-360. doi: 10.1080/03009480310001641

Gunnarson, B. E., and Linderholm, H. W. (2002). Low-frequency summer temperature variation in central Sweden since the tenth century inferred from tree rings. Holocene 12, 667-671. doi: 10.1191/0959683602h 1579rp

Gunnarson, B. E., Linderholm, H. W., and Moberg, A. (2011). Improving a treering reconstruction from west-central Scandinavia: 900 years of warm-season temperatures. Clim. Dyn. 36, 97-108. doi: 10.1007/s00382-010-0783-5

Harris, I., Jones, P. D., Osborn, T. J., and Lister, D. H. (2014). Updated highresolution grids of monthly climatic observations. Int. J. Climatol. 34, 623-642. doi: $10.1002 /$ joc. 3711

Helama, S., Arentoft, B. W., Collin-Haubensak, O., Hyslop, M. D., Brandstrup, C. K., Mäkela, H. M., et al. (2013). Dendroclimatic signals deduced from riparian versus upland forest interior pines in North Karelia, Finland. Ecol. Res. 28, 1019-1028. doi: 10.1007/s11284-013-1084-3

Helama, S., Meriläinen, J., and Tuomenvirta, H. (2009a). Multicentennial megadrought in northern Europe coincided with a global El Niño-Southern Oscillation drought pattern during the Medieval Climate Anomaly. Geology 37, 175-178. doi: 10.1130/G25329A.1

Helama, S., Mielikainen, K., Timonen, M., and Eronen, M. (2008). Finnish supra-long tree-ring chronology extended to 5634 BC. Nor. Geogr. Tidsskr. 62, 271-277. doi: 10.1080/00291950802517593

Helama, S., Timonen, M., Holopainen, J., Ogurtsov, M., Mielikäinen, K., Eronen M., et al. (2009b). Summer temperature variations in Lapland during the medieval warm period and the Little Ice Age relative to natural instability of thermohaline circulation on multi-decadal and multi-centennial scales. J. Quaternary Sci. 24, 450-456. doi: 10.1002/ jqs. 1291

Holmes, R. L. (1999). Users Manual for Program COFECHA. Arizona: Laboratory of Tree-Ring Research, University of Arizona.

IPCC. (2007). "Climate Change 2007: The physical science basis," in Contribution of Working Group I to the Fourth Assessment Report of the Intergovernmental Panel on Climate Change (IPCC), eds S. Solomon, D. Qin, M. Manning, Z. Chen, M. Marquis, K. B. Averyt, M. Tignor, and H. L. Miller (Cambridge; New York: Cambridge University Press).

Karlén, W., and Kuylenstierna, J. (1996). On solar forcing of Holocene climate: evidence from Scandinavia. Holocene 6, 359-365. doi: 10.1177/095968369 600600311
Kaufman, D., McKay, N., Kiefer, T., and von Gunten, L. (2013). A regional view of global climate change. Glob. Change 81, 18-23. Available online at: http://www.igbp.net/publications/globalchangemagazine.4.1b8ae20512db692f2 a680003617.html

Kullman, L. (2007). Tree-line population monitoring of Pinus sylvestris in the Swedish Scandes, 1973-2005: implications for tree-line theory and climate change ecology. J. Ecol. 95, 41-52. doi: 10.1111/j.1365-2745.2006. 01190.x

Kullman, L., and Öberg, L. (2009). Post-Little Ice Age tree-line rise and climate warming in the Swedish Scandes: a landscape ecological perspective. J. Ecol. 9, 415-429. doi: 10.1111/j.1365-2745.2009.01488.x

Lamb, H. H. (1965). The early medieval warm epoch and its sequel. Palaeogeogr. Palaeoclimatol. Palaeoecol. 1, 13-37. doi: 10.1016/0031-0182(65) 90004-0

Länsstyrelsen Jämtlands Län. (2007). Bevarandeplan för Natura 2000-område Vålådalen SE720084. Available online at: http://www.lansstyrelsen.se/jamtland/ SiteCollectionDocuments/sv/djur-och-natur/skyddad-natur/natura-2000/Valad alen_SE0720084_bp4.pdf

Lavigne, F., Degeai, J.-P., Komorowski, J.-C., Guillet, S., Robert, V., Lahitte, P., et al. (2013). Source of the great A.D. 1257 mystery eruption unveiled, Samalas volcano, Rinjani Volcanic Complex, Indonesia. Proc. Natl. Acad. Sci. U.S.A. 110, 16742-16747. doi: 10.1073/pnas. 1307520110

Linderholm, H. W., Björklund, J. A., Seftigen, K., Gunnarson, B. E., Grudd, H., Drobyshev, I., et al. (2010). Dendroclimatology in Fennoscandia-from past accomplishments to future potentials. Clim. Past 6, 93-114. doi: 10.5194/cp6-93-2010

Linderholm, H. W., and Gunnarson, B. E. (2005). Summer temperature variability in central Scandinavia during the last 3600 years. Geogr. Ann. A 87, 231-241. doi: $10.1111 / j .0435-3676.2005 .00255 . x$

Ljungqvist, F. C. (2010). A new reconstruction of temperature variability in the extra-tropical Northern Hemisphere during the last two millennia. Geogr. Ann. A 92, 339-351. doi: 10.1111/j.1468-0459.2010.00399.x

Luckman, B. H., and Wilson, R. J. S. (2005). Summer temperature in the Canadian Rockies during the last millennium: a revised record. Clim. Dyn. 24, 131-144. doi: 10.1007/s00382-004-0511-0

Masson-Delmotte, V., Schulz, M., Abe-Ouchi, A., Beer, J., Ganopolski, A., González Rouco, J. F., et al. (2013). "Information from paleoclimate archives," in Climate Change 2013: The Physical Science Basis. Contribution of Working Group I to the Fifth Assessment Report of the Intergovernmental Panel on Climate Change, eds T. F. Stocker, D. Qin, G.-K. Plattner, M. Tignor, S. K. Allen, J. Boschung, A. Navels, Y. Xia, V. Bex and P. M. Midgley (Cambridge; New York, NY: Cambridge University Press), 383-464.

Nevalainen, L., Helama, S., and Luoto, T. P. (2013). Hydroclimatic variations over the last millennium in eastern Finland disentangled by fossil Cladocera. Palaeogeogr. Palaeoclimatol. Palaeoecol. 378, 13-21. doi: 10.1016/j.palaeo.2013.03.016

Niklasson, M., and Granström A. (2000). Number and zises of fires: long term spatially explicit fire history in a Swedish boral landscape. Ecology 81, 1484-1499. doi: 10.1890/0012-9658(2000)081[1484:NASOFL]2. $0 . \mathrm{CO} ; 2$

PAGES $2 \mathrm{k}$ Consortium. (2013). Continental-scale temperature variability during the past two millennia. Nat. Geosci. 6, 339-346. doi: 10.1038/ ngeo1797

Rosqvist, G. C., Leng, M. J., Goslar, T., Sloane, H. J., Bigler, C., Cunningham, L., et al. (2013). Shifts in precipitation during the last millennium in northern Scandinavia from lacustrine isotope records. Quat. Sci. Rev. 66, 22-34. doi: 10.1016/j.quascirev.2012.10.030

Seftigen, K., Linderholm, H. W., Loader, N., Liu, Y., and Young, G. H. F. (2011). The influence of climate on $13 \mathrm{C} / 12 \mathrm{C}$ and $18 \mathrm{O} / 16 \mathrm{O}$ ratios in tree ring cellulose of Pinus sylvestris L. growing in the central Scandinavian Mountains. Chem. Geol. 286, 84-93. doi: 10.1016/j.chemgeo.2011.04.006

Stokes, M. A., and Smiley, T. L. (1968). An Introduction to Tree-Ring Dating. Chicago: University of Chicago Press.

Travis, D. J., Meentemeyer, V., and Belanger, R. P. (1990). Stressed trees produce a better climatic signal than healthy trees. Tree-Ring Bull. 50, 29-32.

Trouet, V., Esper, J., Graham, N. E., Baker, A., Scourse, J. D., and Frank, D. C. (2009). Persistent positive north atlantic oscillation mode dominated the Medieval Climate Anomaly. Science 324, 78-80. doi: 10.1126/science. 1166349 
Wigley, T. M. L., Briffa, K. R., and Jones, P. D. (1984). On the average value of correlated time series, with applications in dendroclimatology and hydrometeorology. J. Clim. Appl. Meteorol. 23, 201-213. doi: 10.1175/15200450(1984)023\%3C0201:OTAVOC\%3E2.0.CO;2

Young, G. H. F., McCarroll, D., Loader, N. J., Gagen, M., Kirchhefer, A. J., and Demmler, J. C. (2012). Changes in atmospheric circulation and the Arctic Oscillation preserved within a millennial length reconstruction of summer cloud cover from northern Fennoscandia. Clim. Dyn. 39, 495-507. doi: 10.1007/s00382-011-1246-3

Zackrisson, O. (1977). Influence of forest fires on the North Swedish boreal forest. Oikos 29, 22-32. doi: 10.2307/3543289

Conflict of Interest Statement: The authors declare that the research was conducted in the absence of any commercial or financial relationships that could be construed as a potential conflict of interest.
Received: 13 April 2014; accepted: 06 May 2014; published online: 22 May 2014. Citation: Linderholm HW, Zhang P, Gunnarson BE, Björklund J, Farahat E, Fuentes $M$, Rocha E, Salo R, Seftigen K, Stridbeck P and Liu Y (2014) Growth dynamics of tree-line and lake-shore Scots pine (Pinus sylvestris L.) in the central Scandinavian Mountains during the Medieval Climate Anomaly and the early Little Ice Age. Front. Ecol. Evol. 2:20. doi: 10.3389/fevo.2014.00020

This article was submitted to Paleoecology, a section of the journal Frontiers in Ecology and Evolution.

Copyright (C) 2014 Linderholm, Zhang, Gunnarson, Björklund, Farahat, Fuentes, Rocha, Salo, Seftigen, Stridbeck and Liu. This is an open-access article distributed under the terms of the Creative Commons Attribution License (CC BY). The use, distribution or reproduction in other forums is permitted, provided the original author(s) or licensor are credited and that the original publication in this journal is cited, in accordance with accepted academic practice. No use, distribution or reproduction is permitted which does not comply with these terms. 